\title{
THE CONTRIBUTION OF TREE PLANTATION TO HOUSEHOLD WELFARE: CASE STUDY OF PIET RETIEF AND ISWEPE COMMUNITIES
}

\author{
Chidiebere OFOEGBU ${ }^{1}$ \\ ${ }^{1}$ SAFCOL Postgraduate School of Forestry Programme, Department of Plant Production, University of Pretoria, \\ Hatfield 082, Pretoria 001, South Africa \\ *Corresponding email: ofoegbu.c@gmail.com o.chidiebere@tuks.co.za
}

\begin{abstract}
SUMMARY
This paper examines the contribution of industrial tree plantation to welfare of rural households in villages located in the industrial tree plantations in Iswepe and Piet Retief communities of Mkhondo local municipality, South Africa. Systemic random sampling was used to administer questionnaire survey on 120 households. Findings shows that household in these communities enjoy direct benefits such as employment opportunities, and indirect benefits such as provision of housing linked to the social responsibility spending of tree plantation companies operating in the locality. However, households in the study area expressed concern with issues such as lack of access to electricity, poor health and sanitation services. There is therefore need to address issues of concern raised by households in this study in order to improve the overall contribution of tree plantations to rural household's welfare in South Africa.
\end{abstract}

Keywords: tree plantation, forest resources, household, livelihood, rural community.

\section{INTRODUCTION}

Tree plantations provides benefits and key resources, able to help satisfy many human needs, such as socioeconomic needs e.g. as employment, food, health etc.; and material needs e.g. timber, paper etc. (Richardson 2005). In most rural communities across South Africa, forest products are found to be a significant contributor to household's welfare and livelihood (Shackleton et al. 2007). In some instances, forest resources serves as reserve of products upon which household's fall back on for either subsistence or income in times of hardships, e.g. crop failure or unemployment (Maduekwe 2008). Firewood, charcoal, poles, timber, mushroom, edible insect, weaving fibre, thatch grass, fodder for livestock, to mention but a few, are some of the forest resources that have been identified in literature to be a major sustainer of rural lives and livelihood in South Africa (Ham 2000, Shackleton 2004 and Mayers 2006).

Moreover, numerous studies (Ham and Theron 2001, Shackleton 2004 and Chamberlain et al. 2005) have explored the dependency of humans on forest resources. Rural households are often involved in harvesting, collecting, processing, consuming and selling tree plantation products and resources to compliment outputs from agricultural activities. For some households tree plantations-based income generating activities can be a major source of income. In addition, there are several indirect benefits attributable to tree plantations. Ham (2000) observed that supply of firewood and poles from tree plantations in the Kentani area of eastern Cape Province South Africa contributes significantly in reducing deforestation rate 
of indigenous forests and woodlands in the area. Reduce deforestation has significant positive impact in maintenance of forest ecological diversity (Lewis et al. 2005). However there has been increasing interest in understanding the specific contribution of tree plantation to rural household's welfare and livelihood (Mamo et al. 2007).

While there are many rural households derive from tree plantations, there are also costs associated with tree plantations that are often borne by poor rural communities sited in tree plantation area. Globally, there are growing strong concern about household welfare and dependence on tree plantations (Fonta et al. 2011). Experience from USA, South America, and Australia shows that tree plantations establishment on private lands often leads to land ownership concentration in the hands of few people, which oftentimes leads to displacement of small landowners and landless people (Charnley 2005). In South Africa context, Lewis et al (2005) reported some common cost of tree plantations, which include: losses resulting from run-away forest fires; damage to crops by wild animals and livestock living in plantation areas; noise and air pollution associated with certain plantation activities (e.g. tree felling, fires, etc); and increasing threats to security attributed to criminal elements taking refuge in tree plantations. In the same vein, Cairns (2000) reported of conflicts in some rural communities of South Africa over competing land use interest for tree plantation and livestock grazing. In a related development, tree plantation industries are often charged with perpetuating low-wage labor and poor conditions of employment in some rural communities in South Africa (Mayers 2006). At the same time, there are increasing concerns that job creation through tree plantations are irregular and cannot sustain rural livelihood development (Mayers 2006).

However, most effort till date to investigate the contribution of forestry to household's welfare and livelihood in South Africa has focused on natural forests especially in the Eastern Cape Province (e.g. Shackleton 2004). Only very limited study have tried to investigate the contribution of tree plantation to household in South Africa (e.g. Chamberlain et al. 2005), however such studies tend to focus majorly on job creation and the contribution of tree plantations to the national GDP. This study is therefore designed to fill this gap by focusing on the overall contribution of tree plantations to household in rural communities of South Africa. The main purpose of the study thus is to investigate the contribution of tree plantations to rural household welfare and livelihood. The study is based on case study analysis of villages sited in the Industrial tree plantations areas in Piet Retief and Iswepe area of Mkhondo local municipality, Mpumalanga Province, South Africa. The study addresses the following research questions:

1. Are there direct benefits accruing to households in adjacent communities from tree plantations in their locality?

2. Are there indirect benefits accruing to adjacent communities from tree plantation in their locality? How do these benefits affect households' welfare?

3. Are there issues of concern expressed by communities as a result of tree plantation in their locality? How do these concerns affect households' welfare?

\section{MATERIALS AND METHOD}

\section{Study Area}

The are a combined total of 56 villages located in the industrial tree plantations in Piet Retief and Iswepe area of Mkhonda local municipality, South Africa. Base on settlement pattern and nearness to plantations, 12 villages was selected for this study. Ten households were randomly selected per village for sampling, resulting in a total sampled population of 120 households. The name of the selected villages and the total number of household contained in each is presented in (table 1) below. 
TABLE 1: Sampled villages and corresponding total number of households

\begin{tabular}{|c|c|c|c|}
\hline Municipality & Main Community & Villages & No. of household per village \\
\hline \multirow{12}{*}{ VHEMBE } & \multirow[t]{6}{*}{ Piet Retief } & Mooihoek & 48 \\
\hline & & Old Belfast & 65 \\
\hline & & Welverdiend & 39 \\
\hline & & Bon Esperence & 34 \\
\hline & & Athalia & 51 \\
\hline & & New Belfast & 37 \\
\hline & \multirow[t]{6}{*}{ Iswepe } & Zoar & 32 \\
\hline & & Riverside & 37 \\
\hline & & Watersmeet & 42 \\
\hline & & The Bends Jabulani & 30 \\
\hline & & New plaas Ingwempisi & 45 \\
\hline & & Geluk & 49 \\
\hline
\end{tabular}

Source: MBP (2005)

\section{Questionnaire design}

The questionnaire contained both open ended and close ended questions. The questions were clear and simple and addressed the study research questions. The questions were aimed at providing information on extent of household's dependence on tree plantation resources visà-vis employment, dependence on timber resources, dependence on non-timber plantation resources, and overall direct and indirect benefits accruing to households from tree plantation companies operating in their locality. Questions to capture issue of concern associated with living in these tree plantations dominated village were also asked. In general the questions were designed in line with guidelines for questionnaire design recommended by Babbie and Mouton (2008).

\section{Survey process}

The interview team for the study comprised of the study facilitator and an interpreter. Given the strategic importance of the interpreter input in ensuring that the study questions are communicated to respondents in their mother tongue (Swanepoel and Beer, 2006); the interpreter was briefed days before the commencement of the study, about the study aims and objectives and also taken through the questionnaire in detail so as to ensure that he has a good understanding of the study objective. Following the approach pattern used by Ham and Theron (2001), the villagers were first briefed about the study objectives, before the actual survey processes starts. Direct observation, face-to-face interview and administration of questionnaire form were the method applied in gathering required data for this study. As recommended by Bless and Smith (1995) the survey process was thoroughly and critically carried out in order to avoid possible bias either from respondents or interpreter (Ofoegbu 2010).

\section{RESULT}

\section{Direct benefit from Tree plantations establishment}

The direct benefits that rural households derive from the industrial tree plantations in their localty includes the following: 


\section{Employment opportunity}

Employment opportunity is a major direct benefit, households derive from tree plantations in their locality. While some of the respondents are directly employed by forest companies operating in their locality, majority are employed by contractors contracted to the forest companies. Nevertheless seventy-five percent $(n=120)$ of the respondents are employed in tree plantations related establishment. The type and category of work that rural households benefits from tree plantation establishments varies: $26 \%$ are engaged in silviculture (tending and maintenance) works, $15 \%$ works as debarkers, $7 \%$ are chainsaw operators, $1 \%$ work as $\log$ pushers, $3 \%$ work as drivers, $3 \%$ work as log stackers, $3 \%$ are engaged in nursery operations (tending and planting of seedlings in the nursery), 3\% work as markers and while $1 \%$ works with charcoal producing companies. The workers also enjoys high levels of employment security; $60 \%$ of workers are permanently employed, $32 \%$ are casuals and only $8 \%$ are seasonal workers. The different category of tree plantation jobs enjoyed by households is shown in (figure 1) below:

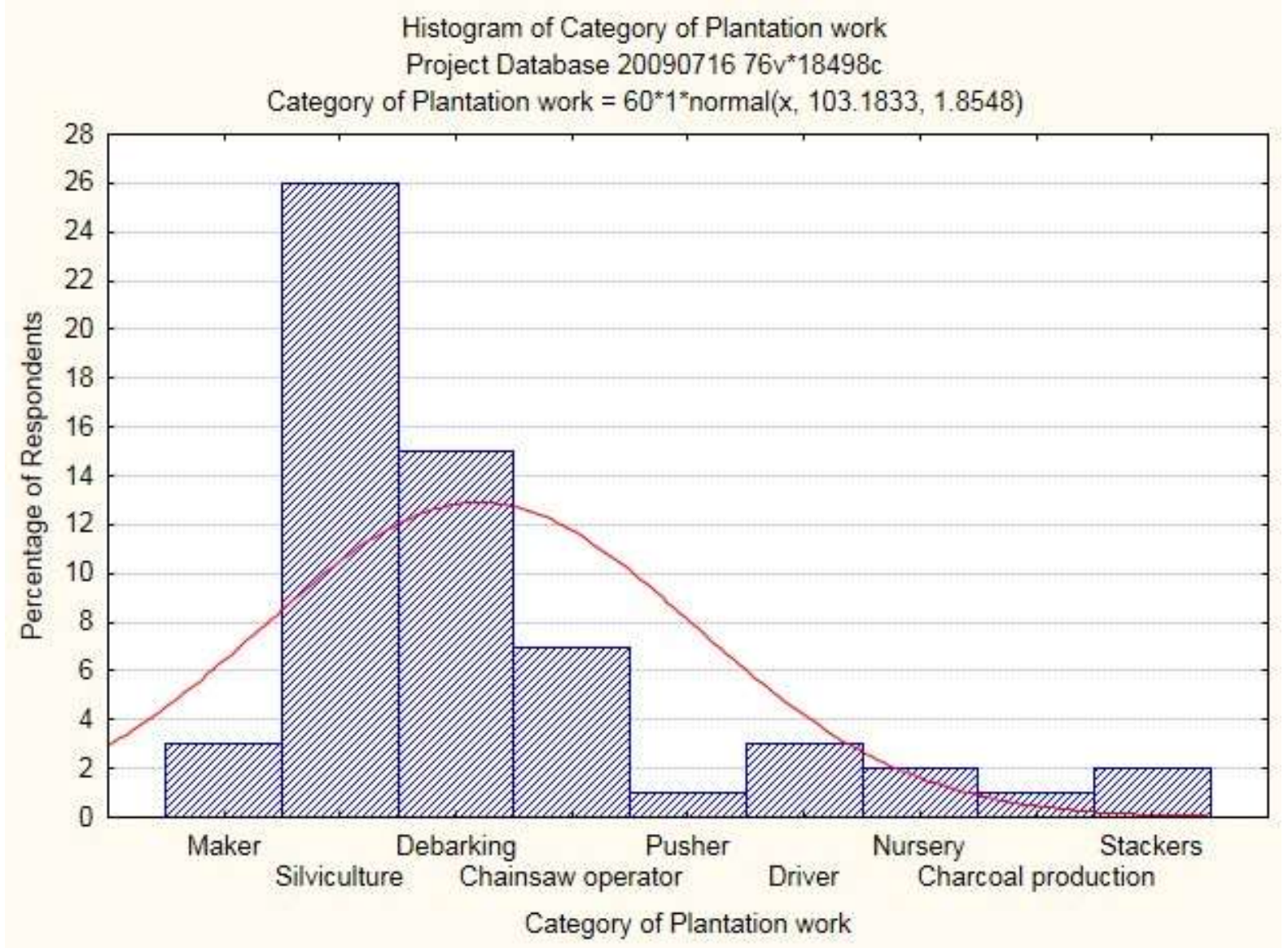

Figure 1: Category of Plantation work

The number of people working in tree plantation related jobs when compared on village to village was found not to be significantly different $(\mathrm{p}=0.24)$, thus employment opportunity is fairly/ equally distributed across the villages. On the average, one person per household is found to be employed in tree plantation related jobs. However, Riverside has the highest mean number of 2.5 person per household employed in tree plantation related job. Mean number of household engaged in tree plantation related jobs is shown (Figure 2) below: 


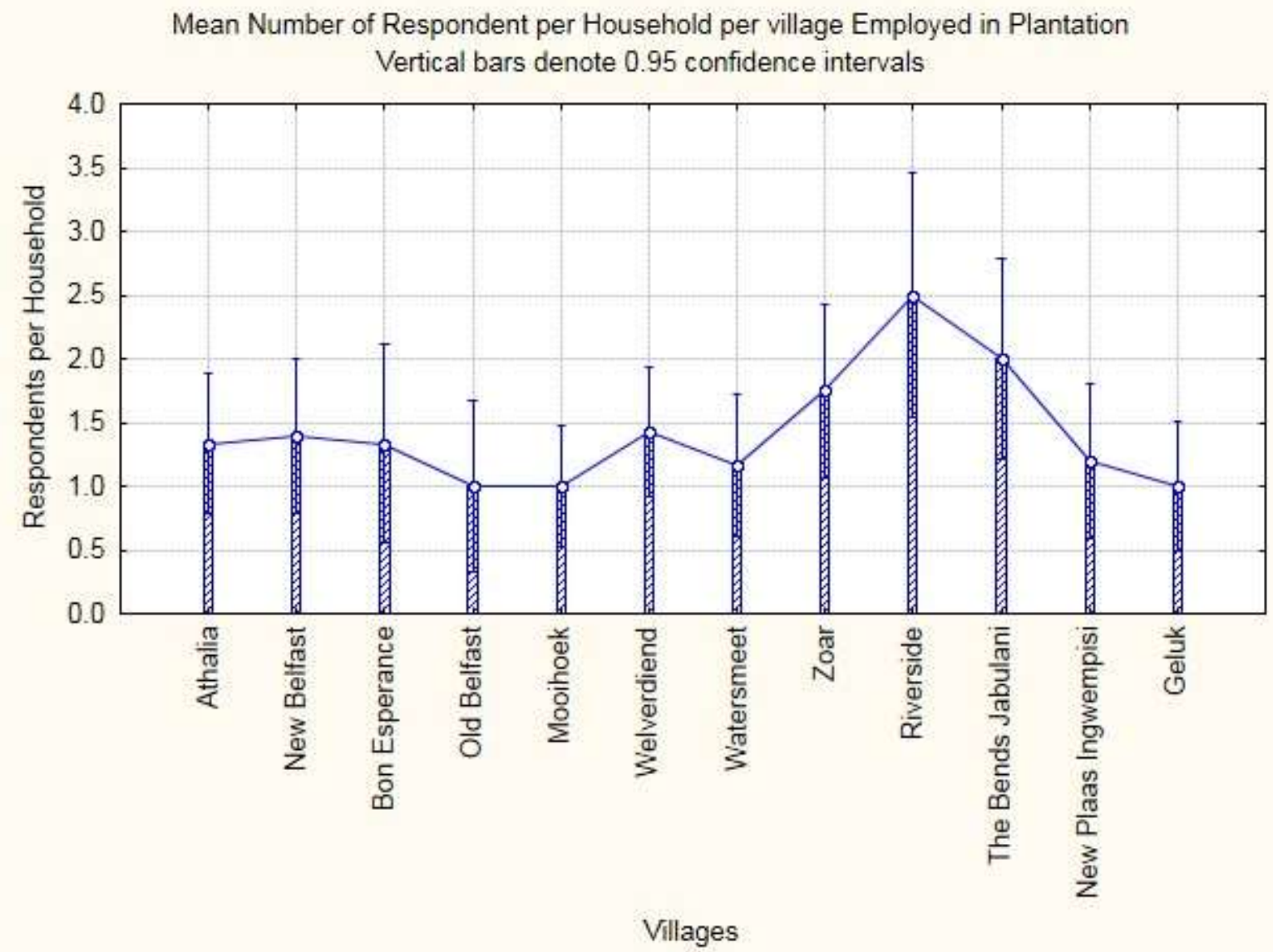

Figure 2: Mean number of household per village in Plantation work

\section{Utilization of woody plantation resources}

Households in the study area enjoy the benefit of free collection and utilization of woody resources. The common woody resources being utilized are timber, pole and harvest residue. Harvest residue gathering was found to be one of the major benefits that the communities derive from the plantation (Plate 1). All household in the villages are involved in collection and utilization of harvest residues. Harvest residues are mostly used as firewood, but are also used for construction of pens for livestock, fencing and house building. On average $740 \mathrm{~kg}$ of residue is consumed per household per village on a monthly basis for agricultural purposes (garden fencing etc). 1,317 kg of residue is consumed per household per village per month for house building, and $946 \mathrm{~kg}$ of residue is consumed per household per month as firewood for cooking.

Plate 1: Pictures illustrating harvest residue utilization

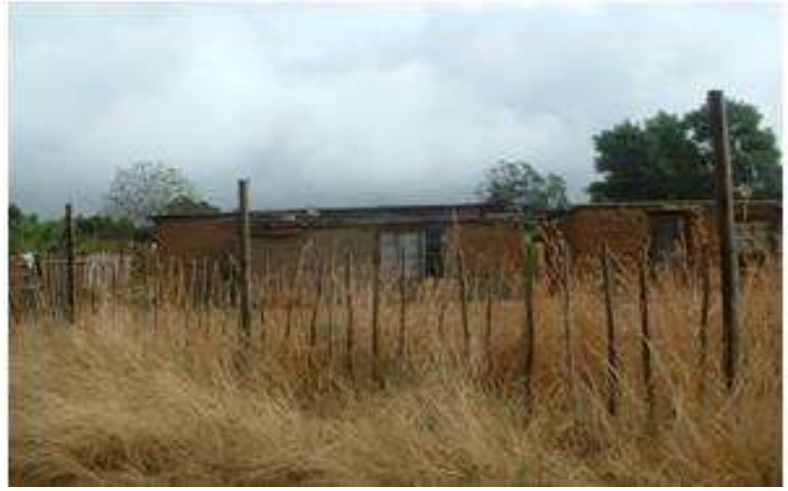


Utilization of non-wood plantation resource

As observed by Sunderland et al (2003) plantation forestry do provide non-timber resources either as a co-product or byproduct. Household's in this study were observed to derive benefits from harvest and utilization of non-wood plantation resources prevalent in tree plantations in their locality. The most prevalent non-wood resources, which the villagers collect, are thatch grass, edible fruits and vegetables, livestock fodder and mushroom. Thatch grass collection and utilization is not a popular activity among the villagers. Only $23 \%$ of the respondents are involved in thatch grass collection because thatch grass collection is mostly done in winter. On average people utilizes $4 \mathrm{~kg}$ of thatch grass per month per household. The number of people involved in thatch grass collection differed significantly $(\mathrm{p}=0.000)$ when compared on village to village basis (figure 3 ).

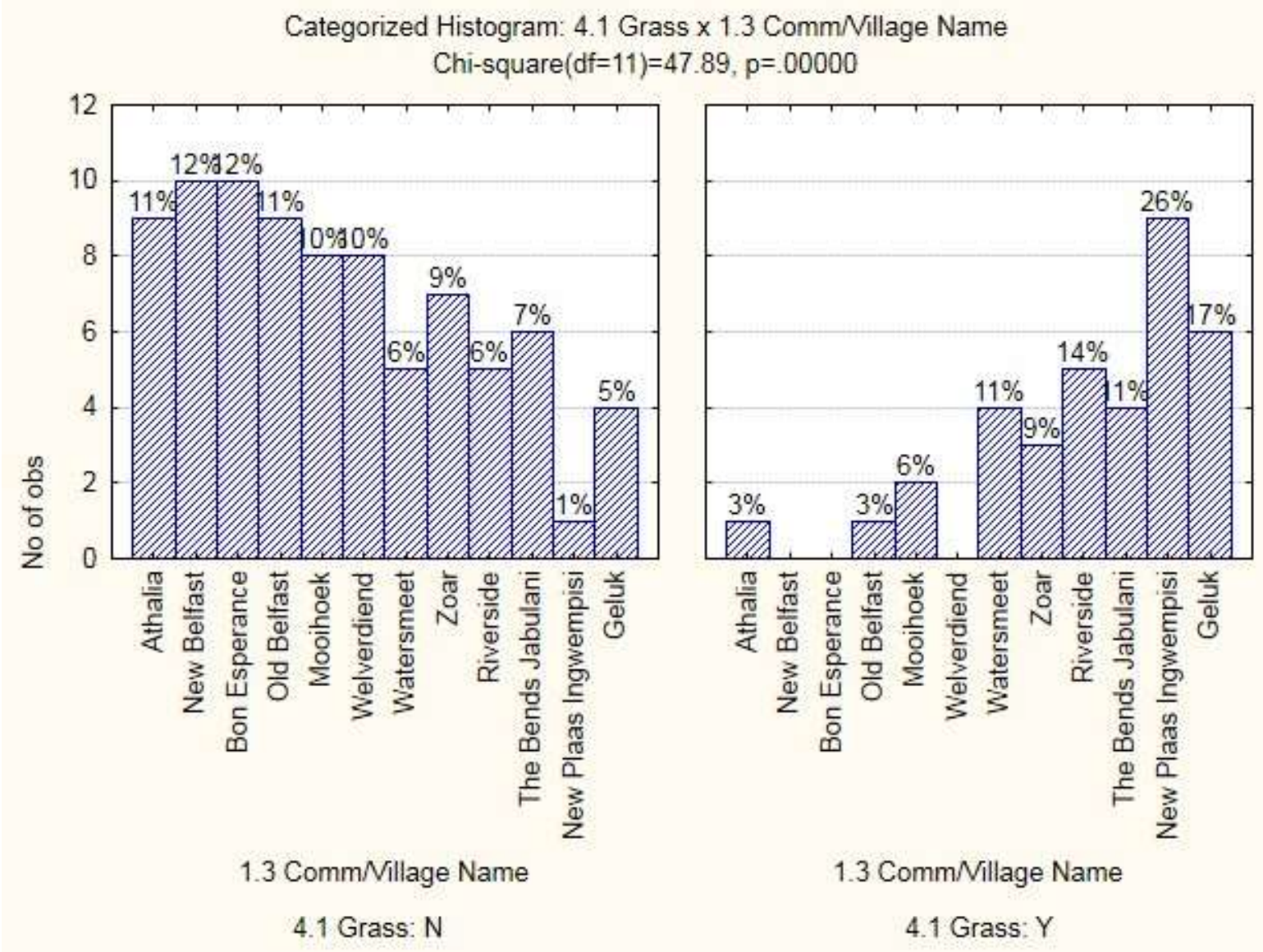

Figure 3: The number of people involved in thatch grass collection

Mushroom collection was practised only at Zoar village and it was reported that $10 \mathrm{~kg}$ of mushrooms is collected per household per month. Fodder collection was only done at Zoar and Geluk where people collect on average $11 \mathrm{~kg}$ of fodder per household per month. Collection of edible fruits and vegetables is practiced only at Old Belfast, Welverdiend, Watersmeet and Geluk. Consumption is on average of $3.5 \mathrm{~kg}$ per household per month. The frequency of collection of these resources varies between villages. Mushroom, thatch grass and edible vegetable and fruit collections are practised three times per week per household. 


\section{Indirect benefit from Tree plantations establishment}

The indirect benefits that rural households derive from the industrial tree plantations in their localty are mostly linked to social responsibility spending of forest companies operating in their locality. Such benefits include the following:

\section{Provision of free accommodation}

The provision of housing in the villages for employees of tree plantation companies in the study area is a significant benefits that households derive from tree plantation companies in their locality. However the nature of these benefits differs immensly. In some villages, the people live in mud/wattle house while in some villages, households live in brick houses provided by the company. In some other villages households are granted controlled access to construction wood and land which they use to build their own houses. Some of the respondents values access rights to harvest timber/construction wood and permits to build house as the same as living in Mondi houses (Plate 2).

Plate 2: Pictures of typical house on provided by tree plantation companies
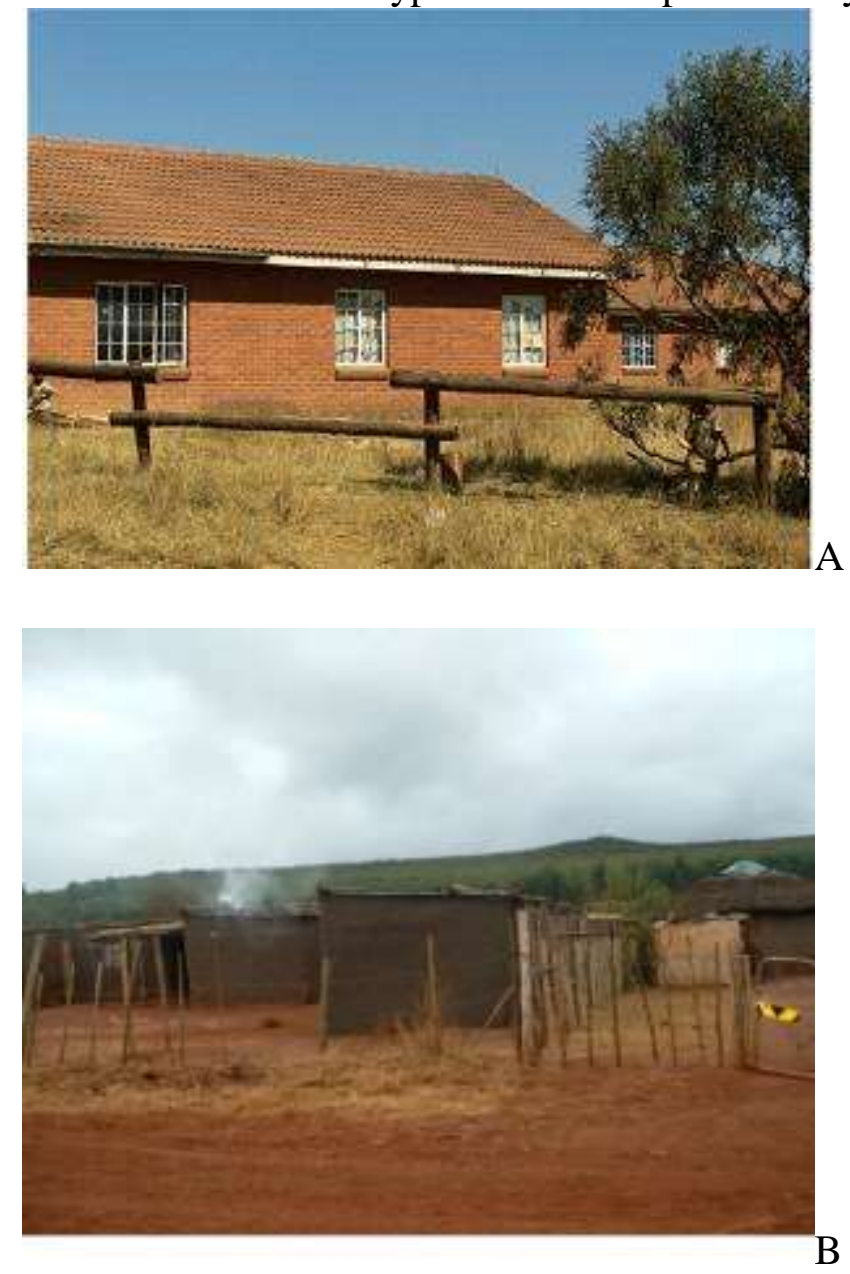

The percentage of respondents who expressed free accommodation as a benefit they enjoy from the tree plantation companies in their locality is presented in (figure 4) below: 


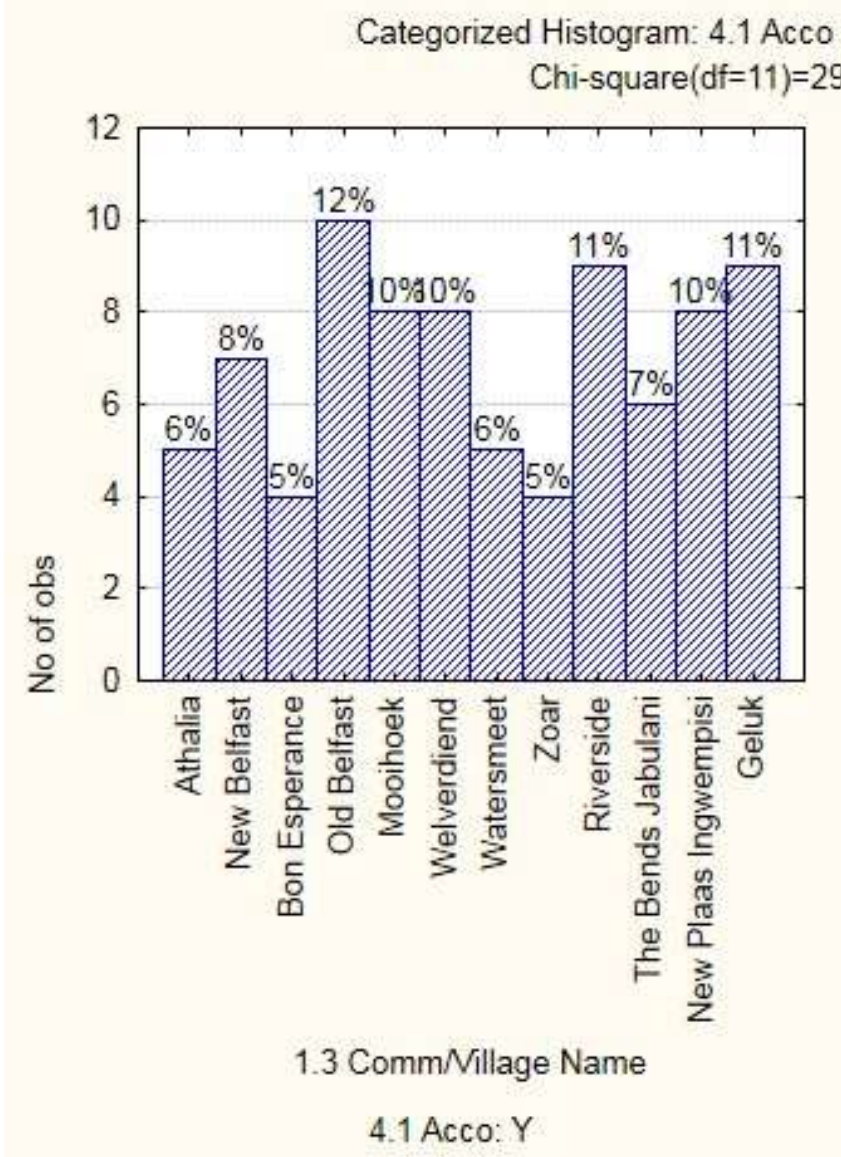

Figure 4: Accomodation benefit

\section{Provision of water supply}

Availability of borehole water is one of the indirect benefits that households derive from forest companies operating in their locality. All the villages are provided with borehole water; however the efficiency of these boreholes and location relative to respondent houses differs from one village to another. Overall water supply to the villages in the study area were rated as satisfactory by $70 \%$ of respondents although some villages experienced supply difficulties. Watersmeet (67\%) and Bon Esperance (50\%) are the villages with the highest level of water supply difficulty.

\section{Provision of farmlands}

Free access to farmland is one of the indirect benefits that households in this study enjoy. Fourty-seven percent of respondents practice farming (farming in the study context means cultivation of crops). The number of people practicing farming was found to differ significantly $(\mathrm{p}=0.000)$ when compared on village to village basis. Welverdiend had no farming activity and only $10 \%$ of the respondents in Athalia, New Belfast and Bon Esperance were practicing farming. In contrast at Zoar $40 \%$ of the community was involved in farming while at Riverside and Geluk 90\% was involved and all respondents were involved in farming at New Plaas Ingwempisi. The percentage of respondents expressing farmland as a benefit they enjoy from tree plantation companies in their locality is presented in (figure 5) below: 

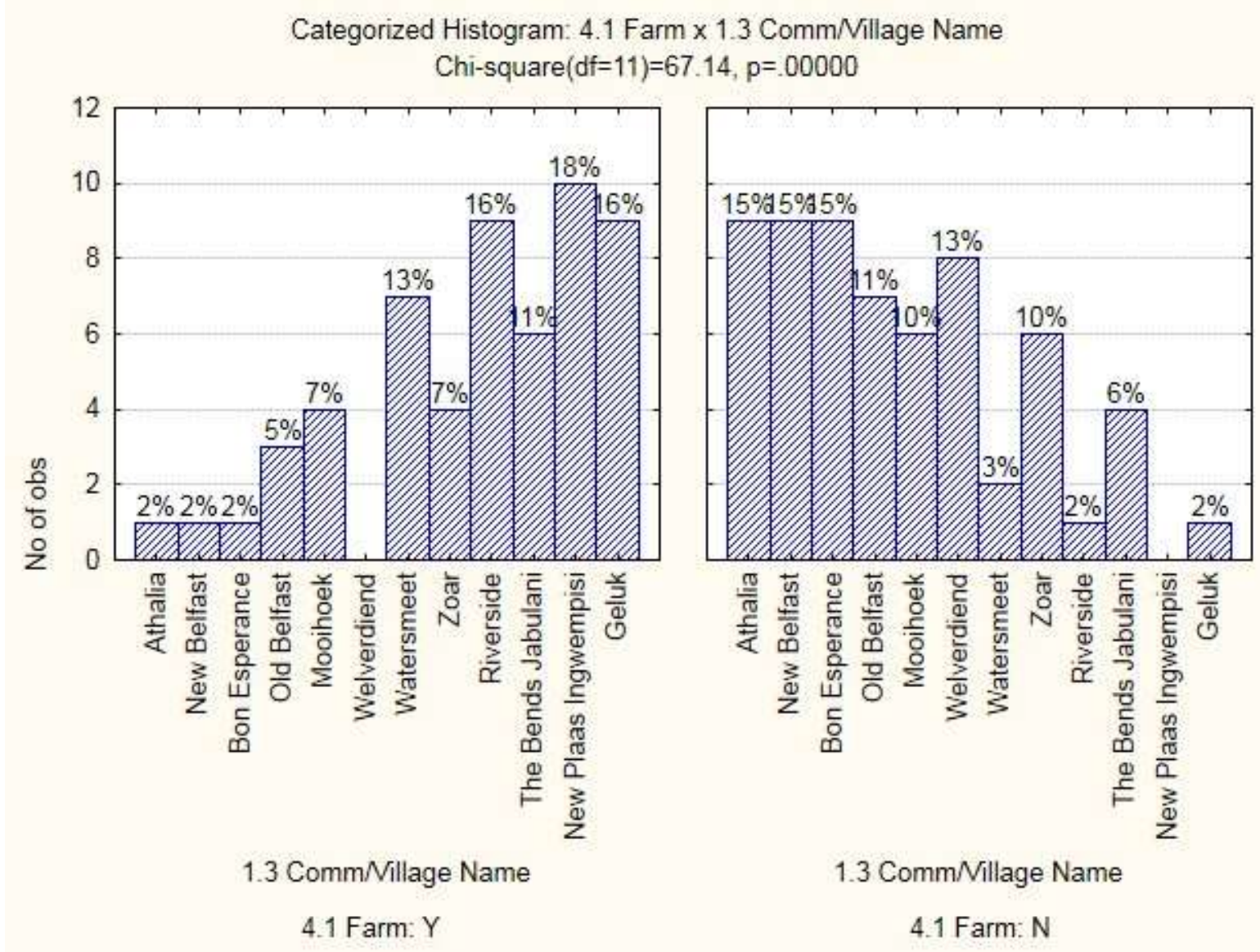

1.3 Comm/Nillage Name

4.1 Farm: $\mathrm{N}$

Figure 5: Farmland benefit

\section{Livestock grazing benefit}

Free grazing of livestocks on open field within the plantations in the villages is of a huge value to households in the study area. livestock keeping is a big part of livelihood diversification strategy that is being practiced by most households in the study area. Tree plantations resources therefore provide household with economic efficient means of feeding their livestock. $48 \%$ of respondents graze their cattle in tree plantations in their area. Few villages e.g. New Belfast and Bon Esperance do not have households that keep livestocks. However, Riverside and New Plaas Ingwempisi have high proportion of households practicing livestock keeping. To be, specific, all respondent in these villages were involved in livestock keeping. Livestock keeping in the rest of the villages were found to be in the order of $10 \%$ in Old Belfast, $40 \%$ in Mooihoek, $13 \%$ in Welverdiend, $78 \%$ in atersmeet, $50 \%$ in Zoar, 60\% in Bends Jabulani and 80\% in Geluk (figure 6). 


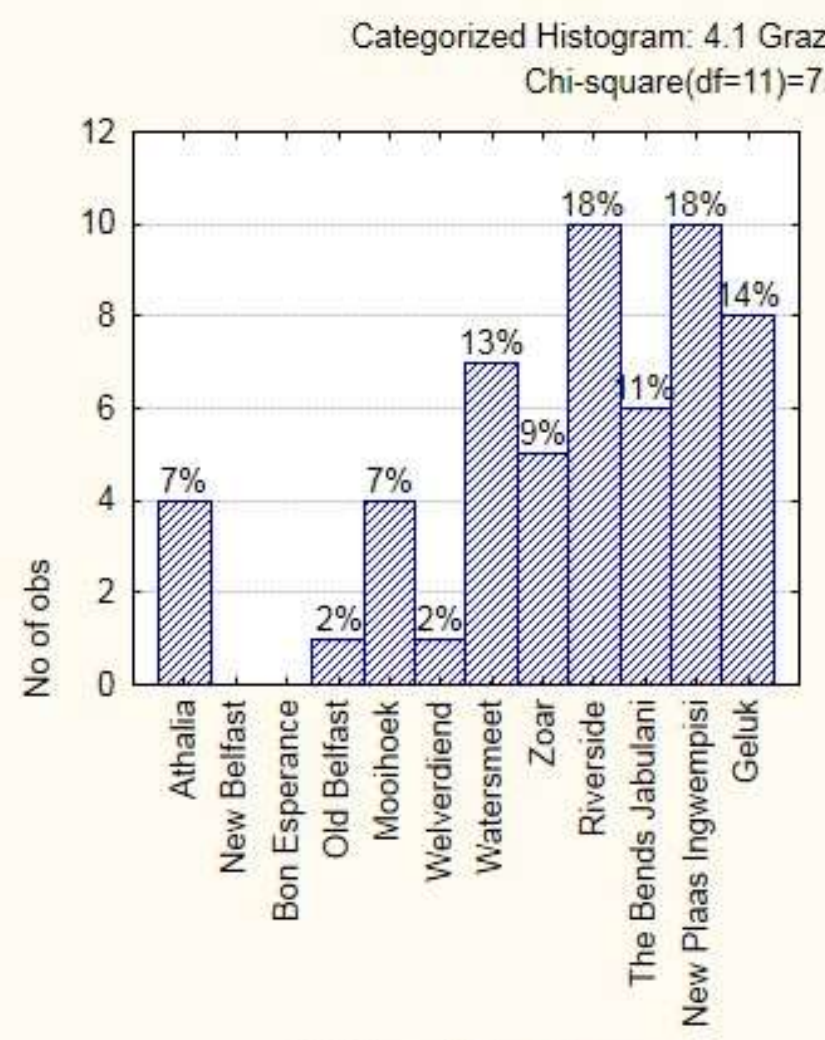

1.3 Comm/Nillage Name

$$
\text { 4.1 Graz: } Y
$$

Figure 6: Livestock grazing benefit

Plate 3: Cattle grazing in tree plantations area

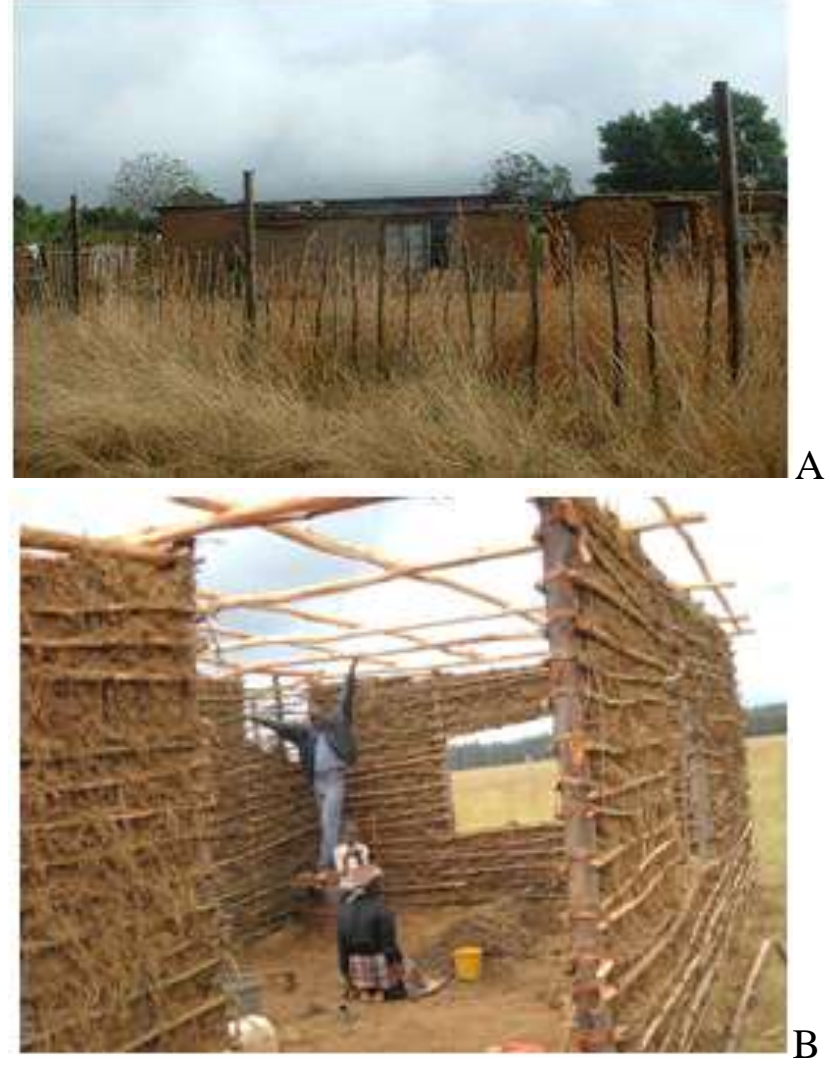

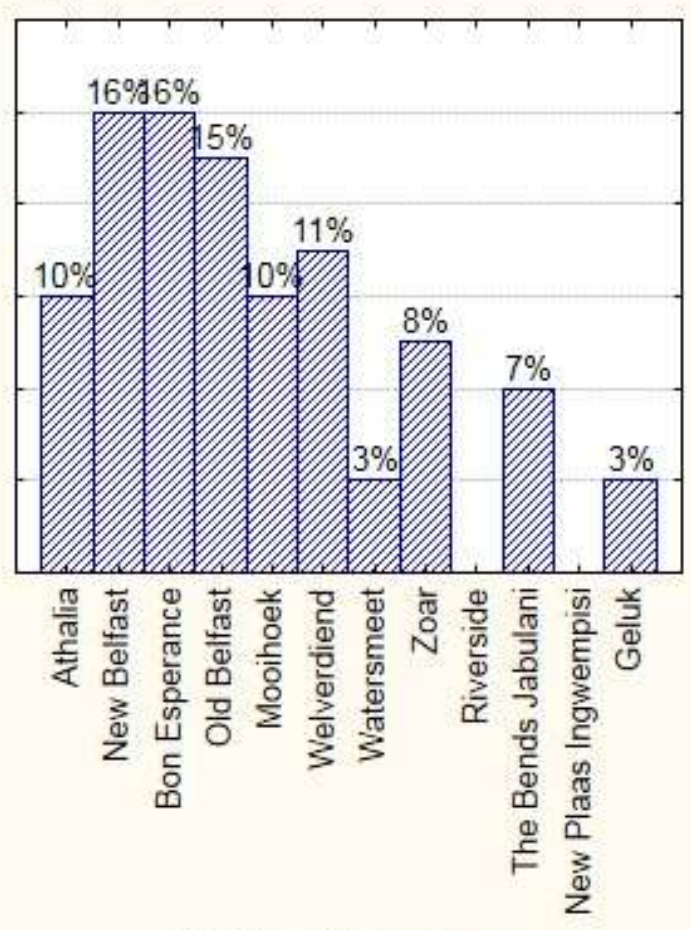

$1.3 \mathrm{Comm} /$ Village Name 4.1 Graz: N 


\section{Social responsibility spending benefit}

Other indirect benefits that households in the study area enjoys that are strongly linked to the social responsibility spending of companies operating in their locality includes: provision of subsidized health services, provision of educational infrastructures like school buildings etc., and provision of cemetry.

\section{Issues of concern expressed by respondents}

The issues of concern expressed by respondents in this study are highlighted in this section:

\section{Poor power supply}

Apart from Watersmeet where nearly all houses are connected to the national electricity grid, all the other sampled villages are not connected to national power grid. Access to electricity was a concern expressed by the communities, however in some places it appears the people are used to living without electricity and hence it was no longer an issue to them. This may possibly explain the reason why only $50 \%$ respondent was found to express lack of access to electricity as a concern. The number of people that noted lack of access to electricity does not differ significantly $(\mathrm{p}=0.011)$ from those that did not acoross all villages (figure 7 ).

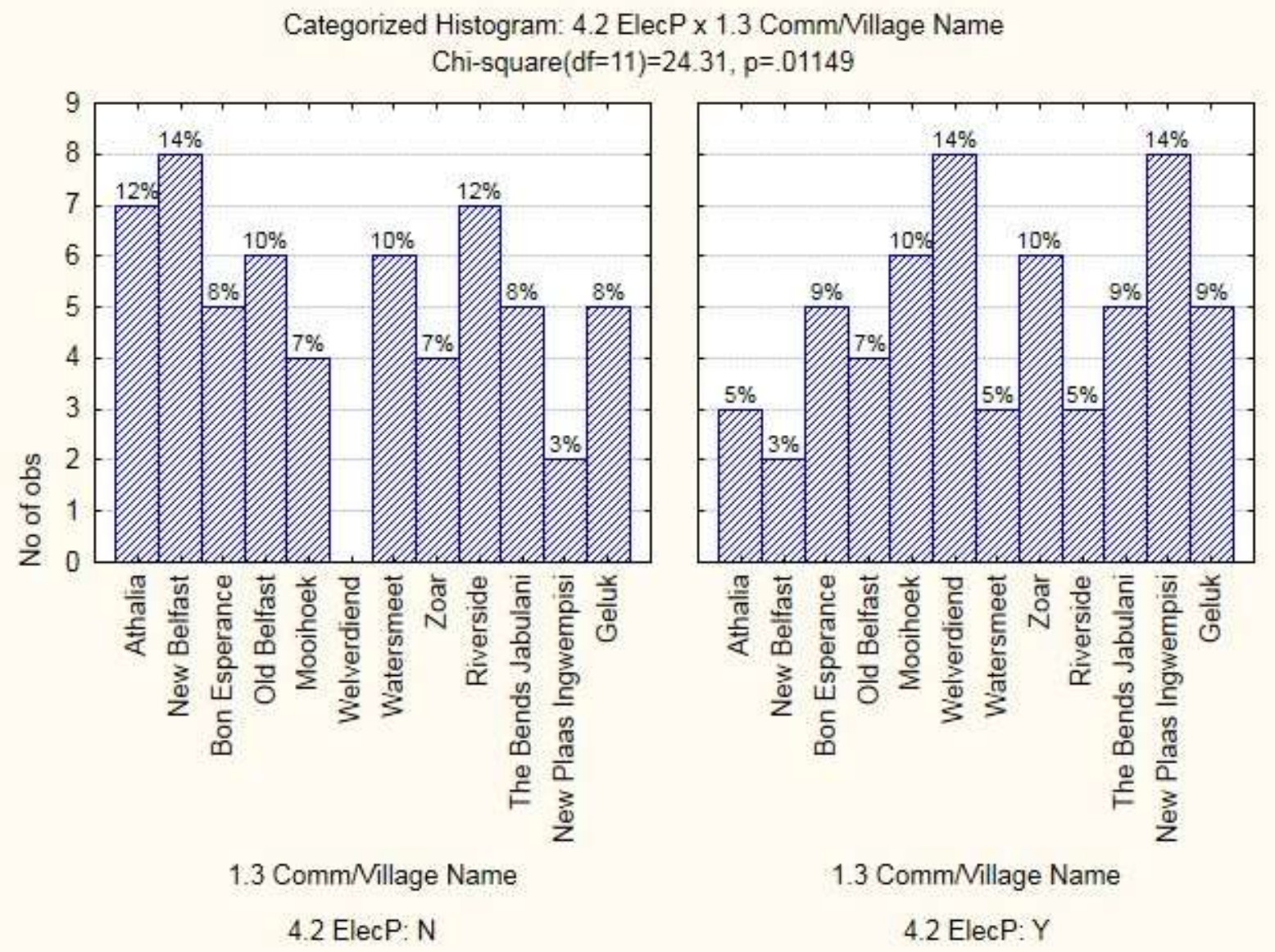

Figure 7: Electricity suppy challenge

Poor sanitation and health service delivery

Twenty-two percent of the repondents expressed their concern about sanitation and health service delivery in their communities. In some villages the health care workers visit them 
only once in a week, which the people complain is not enough especially when there is an emergency or when someone is sick and need regular attendance.

The sanitation issue expressed by the villagers is based mainly on lack of toilets in the area. Some houses in the village do not have a toilet, forcing the people to use open spaces around their dwellings as toilet. This also poses a challenge of its own especially where some have to use the toilet at night. The statistical test shows that expression of sanitation and health service delivery challenge do not differ significantly $(\mathrm{p}=0.697)$ from one village to the other. Thus health service delivery and sanitation challenge is a minor issue and can be assumed to be fairly the same across all the villages (Figure 8).

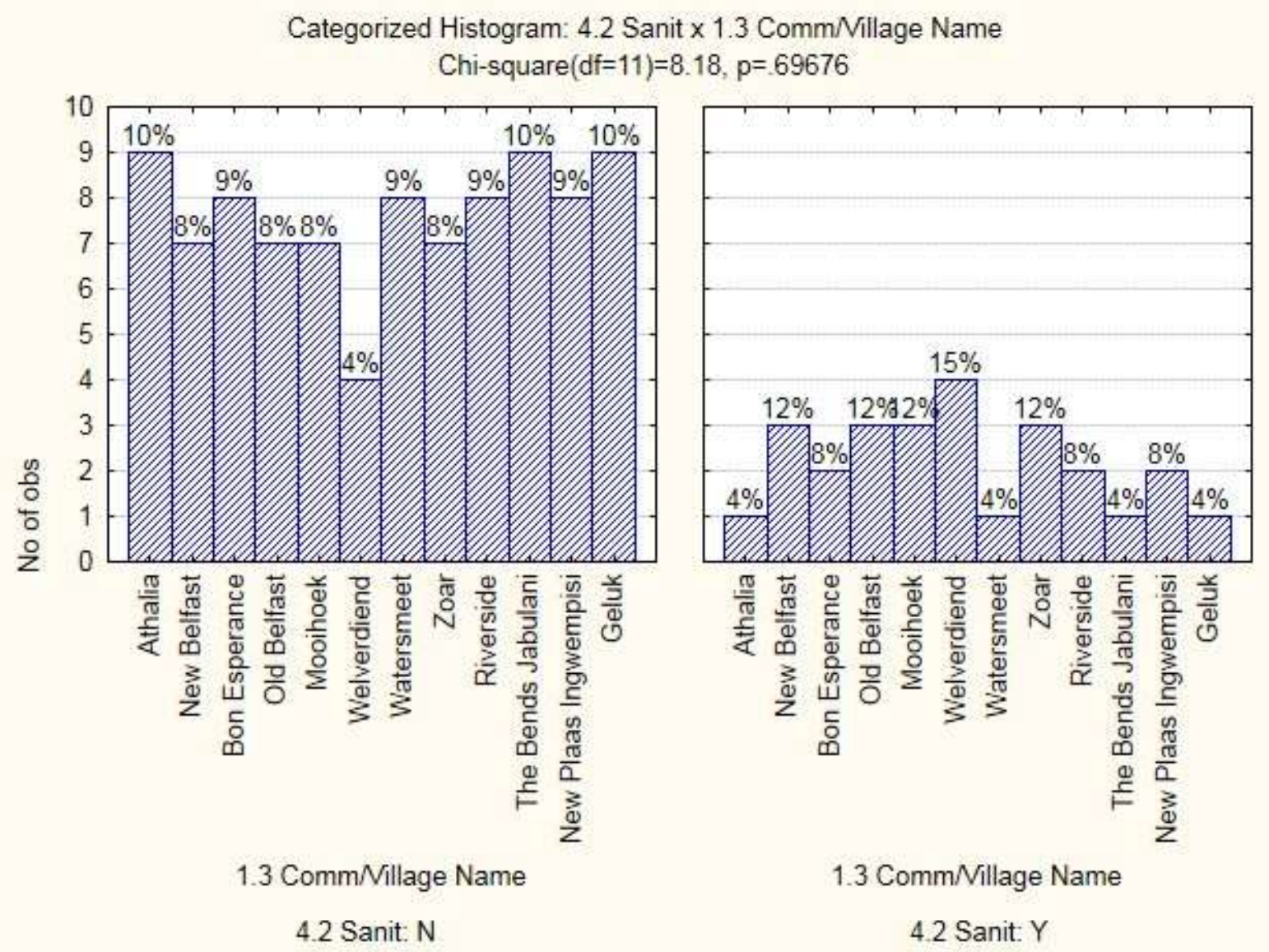

Figure 8: Sanitation and health care issue

\section{Poor transportation services}

Thirty percent of the respondents expressed their disapproval of the transportation system to and fro to work from their villages. Transportation challenge includes poor road conditions, long walking distance to collection points, long waits at the collection points before being transported by contractors to their place of work, and low number of taxis plying the route to the villages.

The transportation problem is highly evident in the difficulty experienced by the people in getting to work. In most villages it takes the people four to five hours to get to their place of work. The long hours spent in going to work and coming back home forces the people to spent large proportions of their time away from home. In trying to solve this challenge the people build houses farther into the forest close to their work place but away from social infrastructures and amenities. 


\section{DISCUSSION}

The creation of employment and business opportunities within the study villages was one of the most significant contribution that tree plantation makes to rural lives and livelihood. Forest companies provide secure job, up to $65 \%$ of the employee are in permanent position, with only $32 \%$ in casual positions. This dismisses the notion that plantation jobs in rural South Africa are mostly casual and seasonal, and cannot provide households with secure source of income. However, total number of direct employment by tree plantation companies need to be increased, given the revelation that most contractors do not comply with the national minimum wage and working condition regulations. The study did found that forest companies in the study area do comply with the national minimum wage regulation and hence contributes significantly in providing households with secure and improved income. Moreover villages in the study area lacks adequate employment opportunities due to their geographical location and lack of infrastructures as was rightly observed by Shackleton (2004), where he states that majority of tree plantations in South Africa are located within the rural areas where forestry plays an important role in the creation of economic activities. Hence the great value and importance attached to tree plantation jobs in the area. This also corresponds with the submission of Chamberlain et al (2005) where they note that tree plantations provides employment mostly in low-income rural areas where economic alternatives are limited and skills are lacking (Chamberlain et al. 2005).

The consumption of abundant forest resources; both woody and non-timber resources in the area provides household with cash saving benefits. Although households are not allowed to sale woody resources such as firewood, poles, timber and construction wood collected from the plantations; they however play a significant role in providing households with cash saving benefits. Most households in the study area uses firewood for cooking, heating and lightening, which is a significant activity in their daily living. This translates to a significant cash saving benefit since the money they would have used in buying such commodity are transferred to other household needs. Moreover cultivation of food crops on farmland freely made available by companies do contributes significantly in providing household with secure livelihood. Households are able to grow their own food which provides them with cash saving benefits, and on few occassions they are able to sale their excess harvest. This also provides household with income diversification benefit while helping to improve their resilience to shocks and uncertainties. Free grazing of livestocks in plantaions also provides houshold with a good income diversification strategy. Livestock are often used by household as stock which are often traded for liquid cash in terms of crisis/need. Cash saving benfits of tree plantation as observed in this study corresponds with safety net and poverty reduction roles of plantations forestry as observed by Vedeld et al (2004) and Shackleton (2004) where forestry plays a major role in helping rural communities survive periods of crisis i.e. period of food scarcity and low income. It can thus be said that tree plantation contributes significantly to households income in the study area either directly through cash saving mechanism or indirectly by providing them with free fooder for their livestock which are often traded for income generation.

Social responsibility spending of companies on infrastructures and services such as electricity, boreholes, cemeteries and health care in the study villages were found to be one of the dominant benefits that endeared the rural communities to forest companies operating in their locality. Social spending of companies in most cases provides a win-win scenario; serving as essential tool for companies to manage social risk in order to maintain forestry activity (Cairns 2000). Most plantation workers are housed in company houses, which are serviced with water and sanitation, and in few instances with electricity. This corresponds with the findings of Cairns (2000) where they reported that forestry companies in South Africa are often the dominant social and development services providers in the villages where 
they operate. This finding also relates with Ham's (2008) observations where it was reported that through social responsibility programmes, forest companies work with local communities to establish for instance gardening groups, sports programmes and small business ventures in order to promote cordial relationship.

Challenges associated with electricity provision as identified in this study include: unavailability of electricity for cooking and house heating and the resultant inability to use facilities such television, radio etc. It is however difficult to determine the extent to which challenges of electricity provision have affected rural life in a broader context. Though electricity provision was an issue it was not significant. This correlates with Gugushe (2006) where it was reported that in some villages in the former Ciskei area of South Africa, most villagers prefer firewood for cooking and house heating despite the fact that they have access to electricity. Therefore it is possible that even if villagers in the study area are provided with electricity, they might still not be able to afford it.

The main concern with transportation as observed in this study is centered on difficulty in getting commercial taxis to commute between the villages and Piet Retief or Iswepe main town and also on the poor condition of some of the roads that link the villages with the main town. Transportation concern such as difficulty in getting commercial vehicles to ply the village route is an issue that characterizes most rural communities around the world (Irwin, 1978). However, this type of challenge can be solved through integrated approach by both forest companies and the municipality.

While there are concerns about living in tree plantation village as expressed by respondents in this study; It can however be conclusively stated that households in this study enjoy both direct and indirect benefits from tree plantation companies in their locality that out-weighs the cost of tree plantations operations in their area. However, in order to improve the benefits that households derive from tree plantation companies operating in their locality and efficiently manage expressed issues of concern, the following recommendations are made:

* Enabling access to forest resources alone cannot solve the livelihood problems of the communities (Gugushe, 2006). Because of the important role of forestry in integrated rural development, it is thus recommended that forest companies and the Mkhondo municipality improve on their partnership in addressing the need of the rural communities;

There is need for forest companies to put measures in place for monitoring contractors contracted to them so as to ensure that the contractors comply with national working conditions regulations and minimum wage requirements.

\section{ACKNOWLEDGEMENT}

I am grateful to the International Tropical Timber Organization (ITTO) for sponsorship received through the Freezailah Fellowship scheme; and to the Commonwealth Forestry Association for sponsorship received through the Young Scientist Research Award, which are all geared towards my MSc Thesis study from which this article is excerpted from. The valuable suggestions made by Cori Ham, Mike Jacobsen, and Dirk Laegin during the initial MSc thesis study are gratefully acknowledged. Opinions expressed and conclusions arrived at, are those of the author and are not necessarily to be attributed to either International Tropical Timber Organization or Commonwealth Forestry Association. 


\section{REFERENCES}

BABBIE, E. and MOUTON, J. 2008. The practice of social research South African edition. Oxford University press Southern Africa (pty) Ltd.: pp150-265.

BLESS, C. and SMITH, C.H. 1995.Fundamentals of social research methods: An African perspective $2^{\text {nd }}$ edition. Juta and Co, Ltd South Africa: pp50-78.

CAIRNS, R. I. 2000. Outgrower Timber Schemes in Kwazulu-Natal: Do they build sustainable rural livelihoods and what interventions should be made? Instruments for sustainable private sector forestry, South Africa series. International Institute for Environment and Development and CSIR-Environmentek, London and Pretoria.

CHARNLEY, S. 2005. Industrial plantation forestry: do local communities benefit? Journal of Sustainable Forestry, volume 21, issue 4: pp 35-57.

CHAMBERLAIN, D., ESSOP, H., HOUGAARD, C., MALHERBE, S. and WALKER, R. 2005. Part I: The contribution, costs and development opportunities of the Forestry, Timber, Pulp and Paper industries in South Africa. Final report-29 June 2005. Genesis Analytics (Pty) Ltd. South Africa.

FONTA, W., ICHOKU, H. and AYUK, E. 2011. The Distributional Impacts of Forest Income on Household Welfare in Rural Nigeria. Journal of Economics and Sustainable Development, 1-13.

GUGUSHE, N.M. 2006. Forest resources use and management in two villages in the former Ciskei, South Africa. Master thesis work, Stellenbosch University South Africa.

HAM, C. 2008. Raising the contribution/profile of forestry to rural development. Report compiled for the FAO national forest programme facility and the Department of Water Affairs and Forestry.

HAM, C. 2007. Green Labelling: Investigation into the marketing of FSC certified timber along the domestic timber value chain in South Africa. MBA thesis work, Stellenbosch University South Africa.

HAM, C. 2000. The importance of woodlots to local communities, small scale entrepreneurs and indigenous forest conservation- A case study instruments for sustainable private sector forestry, South Africa series. International Institute for Environment and Development and CSIR-Environmentek, London and Pretoria.

HAM, C. and THERON, F. 2001. Community forestry resource: a case study of selected woodlots in the Eastern Cape Province. Southern African Forestry Journal- No. 191: pp 65-74.

IRWIN, L.H. 1978. Transportation problems and research needs in the rural sector. Transportation research board, issue number 187

LEWIS, F., ADIE, H., HOWARD, M., MITCHELL, F., STEPHEN, B., HAM, C., OELOFSE, C., BROWN, F. and MANDER, M. 2005. Pilot State of the Forest Report: A pilot report to test the national criteria and indicators, Report prepared by Institute of Natural Resources. Investigational Report Number: 253 for DWAF. 
MAMO G., SJAASTAD E. and VEDELD P. 2007. Economic dependence on forest resources: A case from Dendi District, Ethiopia. Journal of Forest Policy and Economics Volume 9, 916-927.

MAYERS, J. 2006. Poverty Reduction through Commercial Forestry: What evidence? What prospects? The Forest Dialogue, Research paper, No 2. A TFD Publication Number 2.

Mondi Business Paper South Africa (MBP). 2005. Mondi Business Paper Socio Economic Assessment Report (SEAT)

MUDEKWE, J. 2008. The impact of subsistence use of forest products and the dynamics of harvested woody species populations in a protected forest reserve in Western Zimbabwe. Doctorate Thesis, Stellenbosch University, South Africa.

OFOEGBU, C. 2010. An evaluation of the socio-economic impact of timber production with and without the inclusion of biomass energy production. MSc Thesis, University of Stellenbosch, South Africa.

RICHARDSON, J. 2005. Sustainable production systems for bioenergy: Impacts on forest resources and utilization of wood for energy. Biomass and Bioenergy 30: pp 279-280.

SHACKLETON, C.M. 2004. Assessment of the livelihoods importance of forestry, forests and forest products in South Africa, Rhodes University, Grahamstown.

SHACKLETON, C.M., SHACKLETON, S.E., BUITEN, E. and BIRD, N. 2007. The Importance of Dry Woodlands and Forests in Rural Livelihoods and Poverty Alleviation in South Africa. Forest Policy and Economics 9: pp 558- 577.

SWANEPOEL, H. and BEER, F.2006. Community Development: Breaking the cycle of poverty, $4^{\text {th }}$ edition. Juta and Co, Ltd South Africa: pp 350- 400.

VEDELD, P., ANGELSEN, A., SJAASTAD, E. and BERG, G.E. 2004. Counting on the Environment: Forest Incomes and the Rural Poor. Environmental economics series, Paper no. 98. The World Bank Environment Department. 